\title{
Survivors' experiences with testifying in trials after gross human rights violations in Argentina
}

\author{
Anne Margrethe Sønneland ${ }^{1}$
}

\section{Key points of interest}

- Testifying in court for survivors of gross human rights violations entails hardships that should be considered in the work of psychosocial accompaniment

\section{Summary:}

In this article the witnesses' experiences with testifying in court trials after enforced disappearances and torture in Argentina during the last dictatorship (1976 - 1983) are explored. The article is based on qualitative semi-structured interviews with 23 survivors of torture and illegal detention.

The study suggests that while witnesses considered the trials to be important, there were several challenges and hardships involved in testifying. These are discussed in relation to Judith Herman's writings about victims in trials. Herman discusses challenges related to being questioned in court, encounters with perpetrators, and fear for the safety of the witness. The present study suggests that having to testify in more than one trial represents still another challenge for witnesses. A main finding is that

1) Associate Professor at Faculty of Social Studies, VID Specialized University. Correspondence to: a.m.sonneland@vid.no the interviewees place emphasis on a strong sense of responsibility related to testifying, both towards those who did not survive and towards society at large. Testimonies confirm that the crimes were intentional and systematic, and to testify is a way of contributing to justice for those who remain disappeared.

Keywords: Enforced disappearances - trials testimony - Argentina

Court trials are among the main ways of dealing with crimes against humanity committed in the recent past. In Argentina, such trials mainly deal with the systematic use of torture and enforced disappearances committed by the last military dictatorship, which ruled the country between 1976 and 1983 . Survivors from clandestine detention centres and prisons, who have endured torture and ill-treatment and seen others be subjected to such treatments, are central witnesses in the legal proceedings. In this article their experiences with testifying in court are explored, both regarding the continuing(ed) enforced disappearances of others, and the violations that they themselves have endured ${ }^{1}$.

1 This article is based on a $\mathrm{PhD}$ thesis defended at the Department of Sociology and Human Geography at the University of Oslo. 
Enforced disappearances were used systematically during the last military dictatorship in Argentina. The National Commission on the Disappearance of Persons, CONADEP, identified 8961 persons who remain forcefully disappeared, yet, the number of victims is uncertain (CONADEP, 1984; Crenzel, 2012). In addition, many were held incommunicado in clandestine detention centres for a period before they were released or imprisoned in ordinary prisons. Those who were detained were subjected to different forms of torture and ill treatment: the use of torture was systematic (Calveiro, 2008; CONADEP, 1984). The military regime mainly targeted persons who were engaged in social or political activities or in the labour movement.

Since 2005, trials related to crimes against humanity were re-opened in the federal court system in most Argentine provinces after almost two decades of amnesty laws, partly due to the insistence of organisations of survivors and relatives of disappeared. The majority of these trials deal with the responsibility of the armed forces and security forces for kidnapping, enforced disappearances, executions and torture; some also with sexual violence and civilian complicity. By August 2021, 20 cases were open in eight provinces (Secretaria de derechos humanos, 2021). There have been 265 sentences, in which 1030 persons have been convicted (Ministerio Fiscal Público de la República Argentina, 2021). The trials last an average of two and a half years (Secretaria de derechos humanos, 2021).

The testimonies of persons who were held detained-disappeared are central in the trials as there is often little evidence besides their testimonies (Varsky, 2011). Testimonies provide critical information where physical and documentary evidence is scarce, and victim testimonies provide narratives of the direct experience with human rights viola- tions (Walling, 2018). The central role of victim-witnesses thus renders it important to gain further knowledge about the victims' experiences with testifying. This article is based on interviews with 23 survivors of illegal detention and torture, and on participation in court hearings. Herman's $(2003,2005)$ descriptions of victims in trials after violence is chosen as a framework for analysing the experiences of survivors who testify.

\section{Enforced disappearances in Argentina during the dictatorship}

Enforced disappearances were a main method of repression during the last military dictatorship in Argentina (Calveiro, 2008; CONADEP, 1984). The truth commission that was established in 1984 to look into the disappearances - CONADEP (1984) - identified 8961 persons who remained forcefully disappeared. The Commission established the existence of numerous clandestine detention centres all over the country, and in its report, Nunca Más, it published information about these centres as well as names of persons who remained disappeared.

The military regime used enforced disappearances systematically (Crenzel, 2012). Enforced disappearances were carried out through clandestine operations (Crenzel, 2018), and became the paradigmatic form of repression (Kersner, 2002). Violence was exercised by groups that were not identified, although it was clear that they belonged to or were authorised by the regime. Victims were chosen by criteria that were difficult to predict (O’Donnell 2010:187). State repression targeted broad segments of society seen as contaminated by subversion (Malamud-Goti 1998:107).

Persons who were detained were usually held in clandestine detention centres, where practices like replacing a person's name with 
a number, blindfolding the person detained, forcing them to live under poor conditions, and using insults as way of addressing them, all formed part of the de-humanisation processes. Death was a constant possibility, and persons detained would not know what would happen to them (Calveiro 2008

\section{Trials related to the enforced disappearances in Argentina}

Argentina has stood out for its policies of dealing with past atrocities since the transition to democracy in 1983 (Crenzel, 2020). Already in 1985, the military Juntas were tried in court, based on information from CONADEP. Five of the nine former junta leaders were convicted and sentenced, two were sentenced to life imprisonment and loss of military rank. Four were acquitted (Ciancaglini and Granovsky 1995:298-299). The trial of the nine leaders was important, as it was the first time that civilians in Latin America held military men accountable for crimes committed by a regime installed through a coup (Bartolomei 1994:292). Following this trial, cases were initiated against personnel from the police and the armed forces. These trials ended with two amnesty laws passed in 1986 and 1987, due to strong pressure from the armed forces. During the 1990s, some trials were nevertheless held related to the kidnapping and later illegal adoption of children of persons who remained forcefully disappeared. Some provinces carried out 'truth trials', which established facts about what had happened and about the fate of the disappeared, but these had no mandate to convict those responsible (Skaar 2005:166). Trials were re-initiated in 2005, after the Supreme Court annulled the amnesty laws from the late 1980s (Guembe, 2005). The trials have wide support in society (Arnoso Martinez et al., 2017).

\section{Studies of victims in trials after gross human rights violations}

Several studies exist addressing the experiences of victims in international trials after wars or armed conflicts. In Argentina, trials are national, and deal with crimes committed by an authoritarian government. The violence can be described as vertical, that is, from the state towards the population (see RohtArriaza, 2013).

The most comprehensive study is that of Eric Stover (2005), who interviewed witnesses appearing before the International Criminal Tribunal for the former Yugoslavia (ICTY). The ICTY had a witness section, which included psychologists. Most witnesses described testifying as a moral duty, to ensure that the truth about the deaths of others was duly recorded and acknowledged. The majority described their overall experience of testifying as being positive; Stover discusses the possibility that this may be related to whether those who were charged were later convicted.

In a survey study of 300 ICTY witnesses Kimi King and James Meernik $(2017 ; 2019)$ found that few of the witnesses experienced re-traumatisation due to testifying. Charters and Vahidy (2009) and Stepakoff et al.(2005) found that the majority of the witnesses - and particularly the victim-witnesses - in the Sierra Leone tribunal had positive experiences from testifying. Among the positive aspects were the possibility to tell the truth and break the silence, and to be listened to and believed. One-fifth of the interviewees reported feeling less anxiety and sadness after testifying (Stepakoff et al., 2005). Two studies indicate that around $20 \%$ of the witnesses felt less safe after testifying in international courts (Horn, Charters, and Vahidy 2009; Stepakoff et al. 2005). Witnesses who are not worried about testifying and who feel respected by the court personnel are more likely to report positive experi- 
ences (Charters \& Vahidy, 2009); further, the relationship between the witness and the legal teams matters (Horn, Charters, and Vahidy 2009).

Nevertheless, studies from the Truth and Reconciliation Commission in South Africa also show that testifying is not necessarily helpful for witnesses (Hamber et al., 2000; Stein et al., 2008; Wilson, 2009). In an overview of trials and truth commissions in the aftermath of gross human rights violations, Martín-Beristaín and colleagues (2010) found that testifying in trials and in truth commissions increases negative emotions and symptoms, and that it cannot be confirmed that testifying helps in healing individual suffering. Yet, participation can contribute to empowering individuals and restoring dignity and trials and truth commissions can reinforce respect for human rights.

\section{Victim witnesses in court trials}

Court trials after crimes against humanity are criminal trials that deal with gross and systematic violations of human rights. Thus, literature about trials after gross human rights violations in particular, as well as literature about victims in criminal trials in general, is relevant for understanding experiences related to testifying in court.

Judith Herman $(2003,2005)$ describes the legal system as a high-risk environment for victims. Her writings are based on her work with victims of the Holocaust and female survivors of rape and sexual abuse in the US. According to Herman, several aspects of court hearings present challenges for victims: Victims have to endure public challenge to their credibility, while they need social acknowledgement and support. Courts have a complex set of rules and procedures, which victims may not know and over which they have no control, while what the victims need is to establish a sense of control and power in their lives. As witnesses, victims often have to respond to questions that do not leave the possibility to construct a meaningful and coherent narrative and do not make it possible for victims to tell their stories in their own way. Courts require victims to relive traumatic experiences by directly confronting the perpetrator, whereas victims need to control or limit their exposure to specific reminders of the trauma. Victims may also fear for their safety because of the risk of retaliation from perpetrators (Herman 2003).

Still, there may be mental health benefits for crime victims in participating in judicial proceedings, Herman (2003) argues. Legal interventions can provide victims with public acknowledgement of their suffering, and restitution for the harm done. A validation and intervention by the legal system can restore victims' trust in the community, which is not possible as long as there is impunity for the perpetrators. Also, it might provide them with greater safety and protection, and may enhance the victims' sense of power to protect others by deterring the perpetrator from committing similar crimes again (Herman 2003:160-161). In contexts of trials and other mechanisms in the aftermath of gross human rights violations, Martín-Beristain and colleagues (2010:6) similarly argue that active participation in trials can enhance self-esteem and perceived control in the long term. For example, Elisabeth Jelin (2010) found that in the trial against the military Junta in 1984, the voice of the victims acquired testimonial value and could be heard and recognised by judges and by society.

There is an assumption in some of the literature written about trials after gross human rights violations that testifying in court has therapeutic or psychological healing effects for victims (Martín-Beristain et al., 2010:2). Political sponsors of international courts 
often promote criminal trials as a way to meet victims' needs, a platform for victims to share their stories, and help focus due attention to their suffering (Ciorciari \& Heindel, 2016).Yet, most of the academic work that refers to similar ideas merely state that such pretence is based on simplistic ideas about healing (Fletcher \& Weinstein, 2002) do not have support in empirical data (Hamber, 2009; Minow, 1998; Stover, 2005) and that trials are not designed for therapeutic impact (Ciorciari \& Heindel, 2016). There is also a wish to establish knowledge about how testifying in trials influence psychological symptoms and whether victims consider the experience of testifying as being positive (see, among others, Charters \& Vahidy, 2009; Horn et al., 2009, 2011).

This said, it may be argued that ideas of testifying in court as healing for the individual victim may be based on our wish for trials to have such a function. Fletcher and Weinstein (2002:592 - 593) suggest that the ideas of trials as a way to meet victims' needs for truth, acknowledgement of suffering, justice and healing come from the literature on treatment of trauma survivors as well as anecdotal evidence. They hold that some legal scholars cite such studies to support their arguments that criminal trials will serve a similar healing function for survivors. However, academic literature on victims in such trials challenge or nuance ideas of trials as healing for victims (see Herman, 2003, 2005; Stover, 2005; Walling, 2018).

Testimonies in court trials form part of the process of gathering proof used in determining whether the defendants are guilty as charged, and the psychological well-being of the witness is not at the centre of what the court is interested in (Herman, 2003; Walling, 2018). Witnesses can contribute with elements that can prove the facts, because they were present at the moment of a crime (Varsky, 2011) and tes- timonies in court are valued for their ability to prove that specific legal violations were committed: witnesses offer insights into the guilt or innocence of the accused (Walling, 2018). The court decides who will testify, mainly on grounds of whether, or how much, a testimony can be used to determine the guilt or innocence of individual defendants (Varsky, 2011). Thus, testimonies in court are not about the needs of the individual victim; they establish the responsibility or lack of responsibility of the defendant. This shapes the ways in which the testimony can be given: Courts are interested in what Stover (2005) refers to as 'restrictive facts'.

\section{The study: victims' perceptions of court trials related to crimes against humanity}

Victims' experiences with court trials after gross and systematic human rights violations is at the core of this project. The aim of the study was to explore how survivors of such crimes and relatives of victims of enforced disappearances perceive and experience trials. Central questions included whether some form of justice has been achieved through the trials, how trials impact on everyday lives of survivors and relatives of persons who were killed or remain forcefully disappeared, and whether the trials are perceived as important for them.

\section{Methods}

The present study represents part of a larger investigation, 'Dealing with the past', where the authors applied a variety of research approaches, including field work, in depthinterviews with survivors of torture and relatives of persons who remain forcefully disappeared, interviews with persons who work professionally in the field, and a review of relevant documents. This article analyses interviews done with survivors of torture and detention, and who have testified in court in 
cases related to crimes against humanity. Interviews were carried out by the author and by mental health professionals affiliated with the Equipo Argentino de Trabajo e Investigación Social (Argentine Team for Psychosocial Work and Investigation (EATIP), a non-governmental organisation that is engaged in work with survivors of illegal detention and relatives of persons who were forcefully disappeared or killed during the last dictatorship in Argentina (1976 - 1983). The EATIP team has extensive experience supporting persons affected by human rights violations and has accompanied witnesses in the ongoing trials related to crimes against humanity (see Kordon et al., 2010). Their advocacy against impunity and for human rights imply that their position in relation to the issues in question is not neutral.

In addition to the interviews, the author has been present in court hearings in four trials, and have listened to numerous testimonies in court between $2010-2014$.

1. Participants: This article is based on interviews with 23 persons, 9 women and 14 men, who were between 50 and 65 years old at the time of the interviews. All had testified in one or more of the trials that were re-opened after 2005 . The selection was strategic and aimed at exploring the experiences and reactions of survivors who were involved in legal process, both in the larger Buenos Aires area and in a province in the centre of the country. Interviewees were recruited in two ways: In court hearings or in gatherings related to the court hearings, as well as through the broader network of the EATIP team.

2. Interviews: The interviews were carried out between February 2010 and December 2014. Informed consent procedures emphasised confidentiality and the option of withdrawing from the study at any time. The interviews were semi-structured, and were conducted in Spanish, taped, and later transcribed. Each interview lasted between one and two hours.

The interviewees were asked about their thoughts and experiences regarding the trials and individual economic reparations, as well as whether they felt that trials led to any sense of justice (Sveaass \& Sønneland, 2015). It was established whether the interviewees were survivors, relatives of persons disappeared, or both.

3. Data analysis: The transcribed interviews were coded and systematised through thematic analysis, through which the author could familiarise herself with the data, coded, and identified themes (Braun \& Clarke, 2006). Among the themes identified were the human rights violations endured and the formal role that the participants held in trials as witnesses and complainants. Discussions with the project leader and the EATIP team helped identify and elaborate on themes, as the researcher has an active role in finding and being open to emerging themes (Braun \& Clarke, 2006).

\section{Findings: experiences with testifying in trials after crimes against humanity}

A short description of what a court room looks like is in order before describing the findings. While court buildings were different, court hearings were organised in similar ways. The four judges were seated in a central space of the room ${ }^{2}$, the defendants were present,

2 In Argentine trials related to crimes against humanity, there are always four judges in order to ensure that the trial can continue if one of the judges become unable to attend. 
there was seating for the public, and there were formal rules as to how a court hearing is to be conducted. There were always security measures surrounding a court hearing; how strict they were, varied. Court hearings could begin late or be suspended or postponed, and the witnesses would often not know beforehand at what time they would testify.

In the following section, we will explore how the five aspects described by Herman as being challenging for victims in trials are present in the interviews. In addition, two topics will be addressed, namely the fact that the majority of the witnesses testified in more than one trial, and testimony as a responsibility towards those who remain disappeared and society at large.

\section{Being questioned in court}

The two first points mentioned by Herman (2003, 2005) - that witnesses have their credibility publicly challenged and that witnesses encounter a complex set of rules and procedures - are interrelated. For many of the witnesses, the rules and procedures of the courts were unknown during the first trials. At the time of the interviews, the witnesses had some knowledge of how trials were conducted.

How strict the rules were for how witnesses could give their testimony varied between courts and judges. Witnesses could be interrupted, asked questions, and confronted with previous testimonies.

The witnesses interviewed planned their testimonies in advance. Many had read through their testimonies from earlier instances, and they had made sure that they remembered names, dates, and important details. In some courts, witnesses were allowed to testify almost without interruptions. In other cases, witnesses received questions from the judge or the legal representatives of the accused, sometimes frequently. Questions could be general or very specific. Which questions were asked and how they were posed influenced on how stressful it was to testify.

Many interviewees had participated in political groups prior to their detention, and were detained because of this activity. For many, it was important to frame the military regimes' use of repression within a political framework. In some courts, witnesses were allowed to give a political analysis of the context in which the enforced disappearances were committed, and to testify as to the damage caused to society at large, not only to individual victims. A few of the interviewees expressed surprised that they were allowed to give a political interpretation. Such political interpretations can contribute to emphasising the political character of the repression, and also the political identity of many of those who remain forcefully disappeared.

\section{Confronting the perpetrators}

Usually, the defendant would be in court when the witness testified. In addition, witnesses could sometimes encounter the defendants outside of the regulated setting of the court.

The defendants were normally present in the court room and would listen to the testimonies presented by survivors. Sometimes, witnesses recognised the defendants as perpetrators of violence towards themselves of others. Some of the interviewees had decided to follow other court cases where the same defendant is present to get used to their presence.

One of the survivors said that seeing the accused in court

made me feel anger, disgust [...]. But satisfaction of seeing them there, too, in addition to the anger. 
Such ambivalence was present in many of the interviews: On the one hand, the defendants were in court because they were being tried for crimes they were accused of committing. On the other hand, there was discomfort in encounters with those who were responsible, and their presence could lead to fear and other reactions.

How witnesses reacted to the presence of the accused when they testified, varied. Some chose to make eye contact with the accused during their testimonies, others tried to ignore them or decided not to look at them. Some addressed the accused directly in their testimony, to let them know that they recognised them or to remind them of their responsibility for torturing the witness or others.

Some witnesses told the authors about encounters with the defendants outside of the courtroom. One had met the defendant in a hallway; another had met the defendant when they were entering the court room. Such encounters were described as being unsettling.

\section{Threats and fears}

Fear for the security of the witness and their families is one of the topics that is present in many interviews. Fear was instilled during the dictatorship, and the existence of threats towards some witnesses confirm that there are reasons to be cautious. Indeed, as one witness indicated:

You do take precautions. Every time I go to the trial, I open the door to see which cars are driving around. Not like a paranoid thing, but like a certain degree of attention. I would even say it is not very useful (woman, survivor)

Only a few interviewees had received threats related to the ongoing trials; one witness had to be moved out of the province before testifying. Threats seem to have been more common during the trials in the 1980 s, and during the first trials that took place after 2005. The disappearance of Jorge Julio López, a key witness in the first court case opened after the amnesty laws were annulled, was mentioned by many during their interview. López disappeared on the day of the verdict, and his whereabouts have not been established since (Rosende \& Pertot, 2013). Still, the majority of the interviewees say that they are not scared. One explained:

What more can they do to me? I am afraid that they might torture me, that frightens me. But that they might kill me? Not anymore. Yes, that they take someone in my family [...], that scares me - but they have not bothered the families (woman, survivor)

A few interviewees emphasised that the families of witnesses and claimants had not been bothered. Some felt protected by the participants in their political groups or the human rights movement. A few had police protection during some periods. Many witnesses received cell phones from the Secretariat of human rights and could get in touch with them if something happened.

\section{Reactions to testifying}

During the trials that were analysed as part of the current study, the testimonies of survivors were always detailed and rendered with calm. While strong feelings and pain could be described in words, it was seldom shown neither in voice nor in body language. One of the women interviewed explained that:

At some point during the testimony, no matter how much you have prepared for the situation, at some point you're back inside the clandestine detention centre. And you have to be aware of that, to protect yourself so 
that it doesn't hurt you more than necessary (woman, survivor)

After the testimony, and off the stage of the trial, some had strong reactions: The majority described feelings of unease, nervousness or guilt after testifying in court. Some described having problems sleeping or eating, or felt absent; a few wanted to cry all the time. In addition, a few describe physical reactions, such as bleeding or pain. While some witnesses had strong reactions, others did not. Some said that testifying brought relief: finally, they had told what they knew and could allow themselves to forget.

The interviewees describe several ways of coping with testifying in court: Family and friends were mentioned as being important elements of psycho-social support, and several survivors noted how they helped them to cope with the discomforts or distress of trials.

\section{Gaining experience: Testifying in more than one trial}

The majority of the witnesses have testified in several trials. Some have been in several detention centres; some provided information about the disappearance or maltreatment of many others. Some had testified in different courts, and before different judges. The second and third time that they were going to testify, they were more prepared for the situation and for the impact that such a situation has on them. Some felt safer testifying in later trials than in the first one, while others found it harder.

To testify about the same events on several occasions has been said to have been tiring and time-consuming for the witnesses. It takes time to prepare a testimony, practically, regarding the testimony itself, and emotionally. On the other hand, testifying in numerous trials involves a learning process: witnesses gain experience and legal knowledge, and may become more confident. After testifying several times, one survivor remarked that 'I am almost a lawyer by now'.

One concern was that testifying to the same crime in several courts could contribute to the trials taking longer: As the trials are extended in time due to the amount of testimonies, some expressed concern that the defendants can remain unpunished as long as the trials go on and there are no sentences.

\section{The responsibility of testifying in court}

The testimonies of survivors are central in these trials. Survivors have often witnessed some of the crimes that are tried in court, and may recognise one or more of the accused as those responsible for detention, torture or ill treatment that they themselves or others have been subjected to. One survivor described the responsibilities that this entailed:

Once I have said whatever little I know, it doesn't matter if I die or not. I think I have lived for this. [...] I've always known that I could not forget, I had no right to forget (woman, survivor)

Many survivors describe a feeling of moral obligation to testify, an obligation to those who did not survive. One of the survivors explained that:

You do not testify on behalf of yourself. You speak for those who were with you (woman, survivor)

This is a point that many of the witnesses addressed in the interviews: Those who survived have a responsibility to maintain the memory of those who were killed or remain disappeared. Several survivors described testifying as a way of elevating to the judicial sphere the memory of those who did not survive, and 
thereby contributing to achieving justice for them through the court trials.

In addition, testimonies in court contribute to establishing and confirming truths about the crimes committed by the last military regime, about what happened to individuals as well as about the repression. In the trials, those accused contributed with little information about the fate of those who were forcefully disappeared. Thus, survivors may be the only persons who could contribute with information about what happened to persons who remain forcefully disappeared. They contributed to confirming that the enforced disappearances did take place, and that the use of enforced disappearances was similar all over the country.

Witnesses testified on behalf of those who did not survive. For the disappeared who were politically active, recalling their activism implied that they could be remembered not only as victims of serious violations of human rights, but also as active persons who were targeted because of their beliefs and activities.

Testimonies can contribute to convictions, and they can contribute to giving or confirming information about individuals who remain forcefully disappeared. Some survivors recognised faces, or voices, or they had other information that could help to identify those responsible and could give specific information about individual perpetrators. This placed pressure on the survivor-witnesses to get the details right. Remembering the details may be even more difficult in the context of a court hearing, with the defendants present, and the lawyers and judges asking questions. Many of the interviewees described a feeling of having forgotten something important after the testimony. Some felt guilt related to not having given a testimony that was 'good enough', or to forgetting some information. A good testimony should serve to perpetuate the memory of those who remain forcefully disappeared:To testify about what happened is mainly about preserving the memory of those who remain disappeared and yield them some justice.

\section{Discussion}

Herman (2003, 2005) describes five aspects of trials that represent challenges for victimwitnesses: 1) witnesses have to endure public challenge to their credibility; 2 ) they are submitted to a complex set of rules and procedures in court; 3) they often have to answer questions that do not give them the possibility to construct a coherent and meaningful narrative, 4) courts require victims to re-live traumatic experiences by directly confronting the perpetrator, and 5) they may fear for their safety.

In trials related to past serious human rights violations, victims are publicly challenged as to their credibility in court (Herman 2003, 2005), by the questions posed by the lawyers of the defendants. As Walling (2018) notes, the veracity of testimonies are often challenged during cross-examination. Those interviewed emphasised the importance of giving a good testimony, a testimony that complied with the court's need for facts, dates, and locations (see Walling 2018:387) and which could contribute to collective memory and to get a conviction of those responsible. Several interviewees gave what they refer to as political testimonies, with a political interpretation of the enforced disappearances. Such testimonies could depict them as persons with agency, defined by more than their status as a victim, and contributed to describing the violence as a deliberate attempt at ending the victims' involvement in political activities rather than as irrational acts of senseless brutality (Snodgrass Godoy, 2018).

Confrontations with perpetrators are an important challenge in trials (Herman 2003, 2005). Witnesses are prepared to see the defendants in court, within the formal limits 
of the court hearings. Seeing the defendant in court is described as being distressing, although some also express content at seeing them on trial for their crimes. Encounters with perpetrators outside of the formal frames of the court are described as being more distressing and is not something that witnesses are prepared for.

Many of the witnesses mentioned fear and concerns about their security. Most stated that they were not afraid, yet take precautions and we aware both of the disappearance of a key witness in an earlier trial and of threats received by others.

In addition to the aspects described by Herman and the discomforts and waiting related to testifying, two topics were particularly salient in the interviews: Experiences with testifying in several trials, and the emphasis on the responsibility towards society at large and towards those who remain forcefully disappeared.

Most of the interviewees had testified in several trials after 2005. They gained experience and legal knowledge. While some said that experience made them more secure about testifying in court, Edelman (2010) suggests that testifying can become increasingly re-traumatising over time. Testifying to the same events on several occasions is time-consuming, and several of the interviewees described the distress that they and other witnesses felt at having to testify on numerous occasions. There was also the concern that so many witnesses testifying to the same event on many occasions might make trials longer, which the defendants might benefit from as it would take more time before they were convicted.

To testify was described as an obligation towards those who remain disappeared, to get them some justice, and to remember them. To testify was also regarded as a responsibility towards society at large, so that these crimes will not be forgotten - and never repeated (see also Arnoso et al., 2012; Arnoso Martinez et al., 2017). Each testimony would contribute to confirming that the enforced disappearances, detentions, and the use of torture were systematic and formed essential parts of the policies of the military regime in Argentina, as Mariana Lagos (2010) also notes in her text about witnesses in the trials.

There is an assumption in some of the literature that testifying can be good or healing for victims, that telling the truth is restorative (Minow, 1998). This aspect was rarely mentioned when interviewees spoke of their experiences in court: testifying seems to be understood not as something that one does for oneself, but as something that was mainly a part of the struggle for truth and justice, for those who remain disappeared, and for society as a whole - for it never to happen again.

\section{Conclusion}

The efforts of survivors and relatives of persons who remain forcefully disappeared have been crucial in getting these cases tried in court in Argentina. Still, to testify in court in cases of enforced disappearances and torture involved both hardships and challenges for survivorswitnesses. Some had to do with confronting the defendants, and with encountering fears and threats. However, testifying in court was described as meaningful and important: Testimonies confirm that the crimes were intentional and systematic, and to testify is a way of claiming and contributing to justice for those who remain disappeared.

\section{References}

Arnoso, M., Ansaloni, S., Gandarias, I., \& Arnoso, A. (2012). Mujeres jujeñas y sobrevivientes: Narrativas del pasado represivo (1976-1983) argentino, consecuencias psicosociales y creencias acerca de la represión. [Women survivors of Jujuy: narratives about the Argentine repressive past, psychosocial consequences 
and understandings of the repression] Revista Mexicana de Sciencias Politicas y Sociales, 57(214). http://www.scielo.org.mx/scielo.php?pid=S0185$19182012000100006 \&$ script $=$ sci_arttext

Arnoso Martinez, M., Muratori, M., Bombelli, J., \& Zubieta, E. (2017). Evaluación de medidas retributivas y restrauratorias luego de pasados políticos traumáticos: Una mirada al caso argentino. [Evaluation of retributive and restorative measures after traumatic political pasts: the Argentine case] Cuadernos FHyCS$U N F u, 52,211-233$.

Braun, V., \& Clarke, V. (2006). Using thematic analysis in psychology. Qualitative Research in Psychology, 3(2), 77-101.

Calveiro, P. (2008). Poder y desaparición. Los campos de desaparición en la Argentina. [Power and disappearance. The disappearance camps in Argentina] Colihue.

Charters, S., \& Vahidy, S. (2009). Testifying in an International War Crimes Tribunal: The Experience of Witnesses in the Special Court for Sierra Leone. The International fournal of Transitional Fustice, 3, 135-149.

Ciorciari, John. D., \& Heindel, A. (2016). Victim Testimony in International and Hybrid Criminal Courts: Narrative Opportunities, Challenges, and Fair Trial. Virginia fournal of International Law, vol 56(2).

CONADEP. (1984). Nunca Más. Informe de la Comisión Nacional sobre desaparición de personas. [Never again. Report of the National Commission on the disappearance of persons] Editorial Universitaria de Buenos Aires/Comisión Nacional sobre la Desaparición de Personas.

Crenzel, E. (2012). From judicial truth to historical knowledge: The disappearance of persons in Argentina. In B. Syndercombe (Ed.), New Beginnings: Argentina \&o South Africa (Vol. 3, pp. 53-64). AfricaRethoric Publishing. http://www. africanrhetoric.org/pdf/10_AYOR $\% 203,2 \% 20$ Martin.pdf

Crenzel, E. (2018). Inside 'State Terrorism': Bureaucracies and Social Attitudes in Response to Enforced Disappearance of Persons in Argentina. Fournal of Human Rights Practice, 10, 268-286.

Crenzel, E. (2020). Four Cases under Examination: Human Rights and Justice in Argentina under the Macri Administration. Modern Languages Open, 1(26), 1-13.

Edelman, L. (2010). Testigos. [Witnesses] In D. Kordon, L. Edelman, D. Lagos, \& D. Kersner (Eds.), Sur, dictadura y después... [South, Dictatorship and afterwards...] Psicolibro ediciones.

Fletcher, L. E., \& Weinstein, H. M. (2002).

Violence and Social Repair: Rethinking the

Contribution of Justice to Reconciliation. Human Rights Quarterly, 24(3), 573-639. https://doi. org/10.1353/hrq.2002.0033

Guembe, M. J. (2005). La reapertura de los juicios por los crímenes de la dictadura militar Argentina/Reopening of trials for crimes committed by the Argentine military dictatorship. Sur - Rede Universitária de Direitos Humanos, 2(3).

Hamber, B. (2009). Transforming Societies after Political Violence. Truth, Reconciliation, and Mental Health. Springer.

Hamber, B., Nageng, D., \& O’Malley, G. (2000). "Telling it like it is...": Understanding the Truth and reconciliation commission from the perspective of survivors. Psychology in Society, 26, 18-42.

Herman, J. L. (2003). The Mental Health of Crime Victims: Impact of Legal Intervention. Fournal of Traumatic Stress, 16(2), 159. Academic Search Ultimate.

Herman, J. L. (2005). Justice From the Victim's Perspective. Violence Against Women, 11(5), 571-602.

Horn, R., Charters, S., \& Vahidy, S. (2009). Witnesses in the special court for Sierra Leone: The importance of the witness-lawyer relationship. International fournal of Law, Crime E Fustice, 37(1/2), 25-38.

Horn, R., Vahidy, S., \& Charters, S. (2011). Testifying in the Special Court for Sierra Leone: Witness perceptions of safety and emotional welfare. Psychology, Crime \& Law, 17(5).

Jelin, E. (2010). Victimas, familiares o ciudadanos/ as? Las luchas por la legitimidad de la palabra. [Victims, relatives or citizens? The struggle for the legitimacy of the word] In E. Crenzel (Ed.), Los desaparecidos en la Argentina. Memorias, representaciones e ideas (1983-2008) [The disappeared in Argentina. Memories, representations, and ideas] Editorial Biblos.

Kersner, D. (2002). Los derechos humanos en la Argentina de hoy. [Human Rights in Contemporary Argentina] In D. Kersner, M. A. Jorge, C. Madariaga, \& A. Martin (Eds.), Pasajes del dolor, Senderos de esperanza. Salud mental y derechos humanos en el cono sur. [Passages of pain, paths of hope. Mental health and human rights in the Southern Cone] EATIP.

King, K. L., \& Meernik, J. D. (2017). The Witness Experience: Testimony at the ICTY and Its Impact. Cambridge University Press.

King, K., \& Meernik, James. (2019). The Burden 
of Bearing Witness. The impact of of testifying at war crimes tribunals. Fournal of Conflict Resolution, 63(2), 348-372.

Kordon, D., Edelman, L., Lagos, D., \& Kersner, D (Eds.). (2010). Sur, dictadura y después. [South, dictatorship, and after...] Psicolibro ediciones.

Lagos, M. (2010). Juicios a represores. [Trials against repressors] In D. Kordon, L. Edelman, D. Lagos, \& D. Kersner (Eds.), Sur, dictadura y después... (pp. 114-125). Psicolibro

Martín-Beristain, C., Páez, D., Rimé, B., \& Kanyangara, P. (2010). Psychosocial effects of participation in rituals of transitional justice: A collective-level analysis and review of the literature of the effects of TRCs and trials on human rights violations in Latin America. International fournal of Social Psychology, 25(1), 47-60. https://doi. org/10.1174/021347410790193450

Ministerio Fiscal Público de la República Argentina. (2021, June 16). Estado actual del proceso de juzgamiento. [The current status of the process of trials] Fiscales.Gob.Ar. https://www.fiscales.gob. ar/lesa-humanidad/estado-actual-del-proceso-dejuzgamiento-256-sentencias-y-1030-personascondenadas-en-causas-por-crimenes-de-lesahumanidad/

Minow, M. (1998). Between Vengeance and Forgiveness. Facing History after Genocides and Mass Violence. Beacon Press.

O’Donnell, G. (2010). Democracia, agencia y estado. Teoría con intención comparativa. [Democracy, Agency and State. Theory with comparative intent] Prometeo libros.

Roht-Arriaza, N. (2013). Editorial Note. International Fournal of Transitional Fustice, 7, 383-392.

Rosende, L., \& Pertot, W. (2013). Los días sin López. El testigo desaparecido en democracia. Planeta.

Secretaria de derechos humanos. (2021, August 3). fuicios de Lesa Humanidad en tiempo real. Juicios de Lesa Humanidad En Tiempo Real. http:// www.juiciosdelesahumanidad.ar/\#!/

Snodgrass Godoy, A. (2018). Making Meaning of Violence: Human Rights and historical memory in the conflict in El Salvador. Fournal of Human Rights, 17(3), 367-379.

Stein, D. J., Seedat, S., Kaminer, D., Moomal, H., Herman, A., Sonnega, J., \& Williams, D. R. (2008). The impact of the Truth and Reconciliation Commission on psychological distress and forgiveness in South Africa. Social Psychiatry and Psychiatric Epidemiology, 43(6), 462-468.

Stepakoff, S., Reynolds, S., Charters, S., \& Henry, N. (2005). The Experience of Testifying in a
War-Crimes Tribunal in Sierra Leone. American Psychological Association, 2(3), 445-464.

Stover, E. (2005). The Witnesses. War crimes and the Promise of Fustice in the Hague. University of Pennsylvania Press.

Sveaass, N., \& Sønneland, A. M. (2015). Dealing with the Past: Survivors' Perspectives on Economic Reparations in Argentina. International Perspectives in Psychology: Research, Practice, Consultation, 4(4), 223-238.

Varsky, C. (2011). El testimonio como prueba en procesos penales por delitos de lesa humanidad. Algunas reflexiones sobre su importancia en el proceso de justicia argentino. [Testimony as proof in legal processes after crimes against humanity. Some reflexions on ther importance in the Argentine process of justice] In Hacer justicia. Nuevos debates sobre el juzgamiento de crimenes de lesa humanidad en la Argentina. [Creating justice. New debates about the trials in cases of crimes against humanity] Siglo Veintiuno Editores.

Walling, C. B. (2018). Insights on victim testimony and transitional justice: A response to Angelina Snodgrass Godoy. Fournal of Human Rights, 17(3), 384-391. Academic Search Elite.

Wilson, R. A. (2009). The politics of truth and reconciliation in South Africa. Legitimizing the PostApartheid State. Cambridge University Press.

\section{Acknowledgemen}

This project was carried out with funding from the Research Council of Norway. I would like to thank the EATIP, in particular Dr. Mariana Lagos, Dr. Diana Kordon and Dr. Darío Lagos, as well as Dr. Nora Sveaass and the anonymous referees for their comments. 